ISSN 1392-3196 / e-ISSN 2335-8947

Zemdirbyste-Agriculture, vol. 103, No. 1 (2016), p. 53-60

DOI 10.13080/z-a.2016.103.007

\title{
Antioxidant activity and gene expression associated with cadmium toxicity in wheat affected by mycorrhizal fungus
}

\author{
Saleh SHAHABIVAND ${ }^{1,2}$, Hassan Zare MAIVAN ${ }^{1}$, Ebrahim MAHMOUDI ${ }^{1}$, \\ Bahram Mohammad SOLTANI ${ }^{1}$, Mozafar SHARIFI ${ }^{1}$, Ali Asghar ALILOO ${ }^{2}$ \\ ${ }^{1}$ Tarbiat Modares University \\ Tehran, Iran \\ ${ }^{2}$ University of Maragheh \\ Maragheh, Iran \\ E-mail: aliasghar.aliloo@gmail.com
}

\begin{abstract}
In this study, the effects of Funelliformis mosseae and Piriformospora indica on wheat growth, enzyme activity and gene expression of catalase (CAT), ascorbate peroxidase (APX) and glutathione S-transferase (GST) in wheat leaves under different cadmium $(\mathrm{Cd})$ toxicity were investigated. Cd exposure reduced plant dry mass and enzyme activities of CAT and APX, but it increased GST activity. The presence of $F$. mosseae and $P$. indica (alone or together) caused an increase in plant dry mass and activities of CAT, APX and GST. In response to Cd exposure, transcriptional level of CAT was decreased but, transcription of APX and GST was up-regulated. Although $F$. mosseae induced the expression of the antioxidant genes, $P$. indica was not detected to have such a strong induction in the genes expression. The results obtained from this study suggest that $F$. mosseae and $P$. indica can be used to alleviate $\mathrm{Cd}$ stress in wheat plants in contaminated soil. Also, no correlation was observed between mRNA and enzyme alterations in some cases, which indicate that post-transcriptional and post-translational regulations may play major roles.
\end{abstract}

Key words: cadmium, Funelliformis mosseae, gene expression, Piriformospora indica, wheat.

\section{Introduction}

Cadmium $(\mathrm{Cd})$ is a toxic trace pollutant with high mobility for plants, animals and humans. It has been revealed that $\mathrm{Cd}$ as a toxic heavy metal causes growth inhibition and even plant death due to its interaction with photosynthesis, respiration and nitrogen assimilation. The main source of $\mathrm{Cd}$ is intake of food, primarily of cereals. Hence, it is necessary to decrease $\mathrm{Cd}$ accumulation in cereals aimed for food production, particularly in wheat which is one of the most frequently consumed cereals. $\mathrm{Cd}$ toxicity is also related to the production of reactive oxygen species (ROS) and alteration of the cellular antioxidant capacity (Smeets et al., 2008). However, the levels of oxidative stress and antioxidants vary with the plant species, and the dosage and period of $\mathrm{Cd}$ exposure. Smeets et al. (2008) showed that $\mathrm{Cd}$ induces oxidative stress and indicated that the antioxidative defense system is moderated by the activation of different antioxidant genes in different organs and cellular compartments.

Plants commonly employ various strategies to neutralize the inhibitory effect of Cd element. For instance, treatments of seedling with $\mathrm{Cd}$ element could induce a 20 -fold increase in the normally spliced transcript, and a 50 -fold increase in an intron-containing transcript. High level expression of the intron-retained transcript does not increase the activity of glutathione S-transferase, and may be used to sequester heavy metals (Kumar et al.,
2013). In another study, late embryogenesis abundant (LEA) proteins have been linked with Cd tolerance. Gao et al. (2012) reported that the transgenic plants showed better growth than the wild plants did, indicating that TaLEA1 provides tolerance to Cd stress. These findings suggest that TaLEA1 confers tolerance to cadmium stress by enhancing reactive oxygen species (ROS)-scavenging ability and decreasing lipid peroxidation. Besides mentioned strategies, nutrient management (particularly the sulphur) is one of the possible ways to overcome $\mathrm{Cd}$ toxicity. $\mathrm{Cd}$ affects the $\mathrm{S}$ element assimilation pathway which leads to the activation of pathway responsible for the synthesis of cysteine (Cys), a precursor of glutathione (GSH) biosynthesis (Singh Gill, Tuteja, 2011). Further, it has been proven that mycorrizal has significant effect on alleviation of heavy metal toxicity. Studies have shown that about $80 \%$ of terrestrial plants, including most agricultural, horticultural, and hardwood crop species are able to establish the mutualistic association with arbuscular mycorrizal fungi (AMF). The benefits of the AMF symbiosis on plant fitness are largely known, such as providing mineral nutrients (especially phosphorus), and ability to overcome biotic and abiotic stresses (Pozo, Azcón-Aguilar, 2007). AMF plants may also express a variety of enzymes that contribute to the control of cellular ROS levels. Superoxide dismutase (SOD) 
neutralizes superoxide anions $\left(\mathrm{O}_{2}^{-}\right)$, and catalase (CAT) and peroxidase (POD) have a role in quenching $\mathrm{H}_{2} \mathrm{O}_{2}$. The findings of Liu et al. (2011) suggest that antioxidant enzymes have a great influence on the biomass of marigold plants, and AMF can improve the capability of ROS scavenging and reduce $\mathrm{Cd}$ concentration in plants to alleviate $\mathrm{Cd}$ stress. Piriformospora indica belongs to the Sebacinales in Basidiomycota (Oelmüller et al., 2009) which has tremendous potential to be used as a biological agent for plant growth promotion, relieving stress conditions and control of plant diseases (Kumar et al., 2011). Because of the multiplicity of factors involved in heavy metal tolerance by AMF, interpretation of this tolerance is not easy.

So, as a follow-up to our earlier work that verified effectiveness of Piriformospora indica on $\mathrm{Cd}$ tolerance in wheat (Shahabivand et al., 2012), the present study was aimed to investigate the effects of two fungal species including F. mosseae (as AMF) and P. indica on alleviation of $\mathrm{Cd}$-induced stress through alteration of antioxidative enzymatic activity and gene expression associated with cadmium toxicity in wheat.

\section{Materials and methods}

Plant materials. Seeds of wheat (Triticum aestivum L.) cv. 'Homa' were obtained from the Dryland Agricultural Research Institute, Maragheh, Iran. Seeds were surface sterilized for 20 minutes in $1 \% \mathrm{NaClO}$, then rinsed with distilled water five times and germinated on wet filter paper in Petri dishes at $25^{\circ} \mathrm{C}$ for $48 \mathrm{~h}$.

Soil preparation. The experiment soil was collected from the surface horizon of Maragheh University Campus farm. It contained $65 \%$ sand, $23 \%$ silt, $12 \%$ clay, $1.2 \%$ organic matter, $0.05 \%$ total $\mathrm{N}, 7 \mathrm{mg} \mathrm{kg}^{-1}$ available $\mathrm{P}, 35 \mathrm{mg} \mathrm{kg}^{-1}$ available $\mathrm{K}, 1.8 \mathrm{mg} \mathrm{kg}^{-1}$ total $\mathrm{Cd}$, having $\mathrm{pH}$ of 7.3 and $1.3 \mathrm{ds} \mathrm{m}^{-1}$ electrical conductivity (EC). The soil samples were air-dried, sieved to pass $2 \mathrm{~mm}$ and were steam sterilized $\left(100^{\circ} \mathrm{C}\right.$ for $1 \mathrm{~h}$, three consecutive days) by autoclaving to eliminate native arbuscular mycorrhizal (AM) fungal propagules as well as other microorganisms. After sterilization, four Cd concentrations $(0,0.3 \mathrm{mM}$ or $33.7 \mathrm{mg} \mathrm{kg}^{-1} \mathrm{Cd}$ soil, $0.6 \mathrm{mM}$ or $67.4 \mathrm{mg} \mathrm{kg}^{-1} \mathrm{Cd}$ soil and $0.9 \mathrm{mM}$ or $101.1 \mathrm{mg} \mathrm{kg}^{-1} \mathrm{Cd}$ soil) were added to the soil (as $\mathrm{CdCl}_{2}$ ). The samples then were incubated at $20^{\circ} \mathrm{C}$ for one month allowing metal to distribute into various fractions and equilibrating with soil solid phase. Deionized water was added to the soils to achieve a moisture content of $70 \%$ field capacity at the incubation period.

Fungal materials. Piriformospora indica (received from professor Goltapeh, Department of Plant Pathology, Tarbiat Modares University, Tehran, Iran) was cultured in Petri dishes on a modified Kaefer medium with the following composition: $20.0 \mathrm{~g} \mathrm{~L}^{-1}$ glucose, $3.0 \mathrm{~g} \mathrm{~L}^{-1}$ peptone, $3.0 \mathrm{~g} \mathrm{~L}^{-1}$ yeast extract, $1.83 \mathrm{~g} \mathrm{~L}^{-1} \mathrm{KH}_{2} \mathrm{PO}_{4}, 0.65 \mathrm{~g} \mathrm{~L}^{-1}$ $\mathrm{MgSO}_{4} \cdot 7 \mathrm{H}_{2} \mathrm{O}, 2.5 \mathrm{ml} \mathrm{L}-1$ micro-elements stock solution, $1.0 \mathrm{ml} \mathrm{L}^{-1}$ vitamin stock solution, $1.0 \mathrm{ml} \mathrm{L}^{-1}$ of $0.1 \mathrm{M} \mathrm{CaCl}_{2}$ solution, $1.0 \mathrm{ml} \mathrm{L}^{-1}$ of $0.1 \mathrm{M} \mathrm{FeCl}_{3}$ solution, $2.5 \mathrm{ml} \mathrm{L}^{-1}$ of $5.0 \mathrm{~g} \mathrm{~L}^{-1} \mathrm{FeSO}_{4} \cdot 7 \mathrm{H}_{2} \mathrm{O}$ and $15 \mathrm{~g} \mathrm{~L}^{-1}$ agar. The microelements stock solution contained $\left(\mathrm{g} \mathrm{L}^{-1}\right): \mathrm{ZnSO}_{4} \cdot 7 \mathrm{H}_{2} \mathrm{O}$, 22.4; $\mathrm{H}_{3} \mathrm{BO}_{3}, 11.0 ; \mathrm{MnCl}_{2} \cdot 4 \mathrm{H} 2 \mathrm{O}, 5.0 ; \mathrm{CoCl}_{2} \cdot 6 \mathrm{H}_{2} \mathrm{O}, 1.6$; $\mathrm{CuSO}_{4} \cdot 5 \mathrm{H}_{2} \mathrm{O}, 1.6 ;\left(\mathrm{NH}_{4}\right)_{6} \mathrm{Mo}_{7} \mathrm{O}_{27} \cdot 4 \mathrm{H}_{2} \mathrm{O}, 1.1 ; \mathrm{Na}_{2}$ EDTA, 50.0. The vitamin stock solution consisted of $0.5 \mathrm{~g} \mathrm{~L}^{-1}$ of biotin, $1.0 \mathrm{~g} \mathrm{~L}^{-1}$ of p-aminobenzoic acid, $5.0 \mathrm{~g} \mathrm{~L}^{-1}$ of nicotinamide, $1.0 \mathrm{~g} \mathrm{~L}^{-1}$ of pyridoxal phosphate solution and $2.5 \mathrm{~g} \mathrm{~L}^{-1}$ riboflavin solution (Kumar et al., 2011). $P$. indica was prepared as follows: circular agar discs inoculated with spores of $P$. indica were placed onto Petri dishes containing modified Kaefer medium and then incubated in an inverted position for 2 weeks at $28^{\circ} \mathrm{C}$ in a temperature-controlled growth chamber. Next, ten fully-grown fungi agar discs $(5 \mathrm{~mm}$ in diameter) were inoculated into individual $500 \mathrm{~mL}$ Erlenmeyer flasks containing $250 \mathrm{~mL}$ of Kaefer broth (with content and density mentioned above except agar). The flasks (the liquid culture) were then incubated with constant shaking at $100 \mathrm{rpm}$ on a rotary shaker for $15 \mathrm{~d}$ at room temperature in the dark. The amount of $50 \mathrm{ml}$ liquid culture was added to pots that were treated with $P$. indica. F. mosseae inoculum consisted of spores, soil, hyphae and infected maize root fragments supplied from the Department of Plant Pathology, School of Agriculture, Tarbiat Modares University, Tehran, Iran and was produced over a four-month period on maize plants under greenhouse conditions using sterilized sand. The inoculated dosage was $50 \mathrm{~g}$ of inoculum per pot containing approximately 20 spores $\mathrm{g}^{-1}$ soil.

Planting and growth conditions. The experiment was carried out under growth chamber conditions and consisted of a completely randomized $4 \times 4$ factorial design with four replications at University of Maragheh, Iran during years of 2013 and 2014. Pots were filled with $5 \mathrm{~kg}$ of sterilized sandy soil that contained four added $\mathrm{Cd}$ (as $\left.\mathrm{CdCl}_{2}\right)$ concentrations $(0,0.3,0.6$ and $0.9 \mathrm{mM})$. The fungal treatments were: 1) inoculation of Piriformospora indica (50 $\mathrm{ml}$ of liquid culture), 2) inoculation of Funelliformis mosseae (50 g of inoculated soil), 3) coinoculation of $F$. mosseae and $P$. indica $(50 \mathrm{ml}$ of liquid culture $+50 \mathrm{~g}$ of inoculated soil) and 4) non-inoculated (control). P. indica and F. mosseae inoculums were placed $2 \mathrm{~cm}$ below the wheat seedlings at transferring (from filter paper into soil) time ( $72 \mathrm{~h}$ after first germination). The experimental pots were placed in a growth chamber under conditions of $14 \mathrm{~h}$ of light, $10 \mathrm{~h}$ darkness, $28 / 20^{\circ} \mathrm{C}$ day/night temperature, relative humidity of $50-65 \%$ and photosynthetic photon flux density of $200 \mu \mathrm{mol} \mathrm{m} \mathrm{m}^{-2} \mathrm{~s}^{-1}$. Watering was done at $72 \mathrm{~h}$ intervals throughout the growth period using deionized water to near field capacity. Plants were harvested after $45 \mathrm{~d}$. (at the beginning of flowering stage) for growth and biochemical analysis. Roots and shoots of the harvested wheat samples were rinsed with tap water to remove soil particles and then were carefully washed with deionized water. The samples were dried in an oven at $70^{\circ} \mathrm{C}$ for $48 \mathrm{~h}$ (to measure the dry weight and $\mathrm{Cd}$ determination).

Cadmium determination. First, the dried plant samples were finely ground $(0.1 \mathrm{~g})$ then, were digested with a mixture $(7: 1, \mathrm{v} / \mathrm{v})$ of $\mathrm{HNO}_{3}$ and $\mathrm{HClO}_{4}$. Cd concentrations in digested solutions were determined using an atomic absorption spectrophotometer ("Shimadzu", Japan).

Root colonization. A small fraction of the root system was carefully washed in tap water, cut into $1 \mathrm{~cm}$ root pieces then cleaned with a $10 \%(\mathrm{w} / \mathrm{v}) \mathrm{KOH}$ solution and finally stained with $0.05 \%(\mathrm{v} / \mathrm{v})$ Trypan blue in lactic acid. The percentage of fungal root length infection, either by hyphae, arbuscules or vesicles of $F$. mosseae microscopically was assessed by the grid-line intersect technique. In $P$. indica-inoculated roots, the distribution of chlamydospores within the root was taken as an index of colonization (Oelmüller et al., 2009). 
Enzyme extraction and activity assay, and $\mathrm{H}_{2} \mathrm{O}_{2}$ determination. For catalase (CAT) extraction, leaf samples $(0.5 \mathrm{~g})$ were homogenized in ice cold $0.1 \mathrm{M}$ phosphate buffer ( $\mathrm{pH} 7.5$ ) containing $0.5 \mathrm{mM}$ EDTA with pre-chilled mortar and pestle. Each homogenate was transferred to centrifuge tubes and was centrifuged at $4^{\circ} \mathrm{C}$ for $15 \mathrm{~min}$ at $15000 \mathrm{~g}$. For APX extraction, $2 \mathrm{mM}$ ascorbate and 5\% polyvinylpyrrolidone were added to the above enzyme extraction solution. The supernatant was used for enzyme activity assay. APX and CAT activities were measured according to Yoshimura et al. (2000). For glutathione S-transferase (GST) extraction, leaf samples $(0.5 \mathrm{~g})$ were homogenized in ice cold $0.1 \mathrm{M}$ phosphate buffer ( $\mathrm{pH}$ 6.8) containing $0.4 \mathrm{mM}$ EDTA, $0.5 \%$ polyvinylpyrolidone (PVP) and $1 \mathrm{mM}$ sodium metabisulfite with pre-chilled pestle and mortar. Each homogenate was transferred to centrifuge tubes and was centrifuged at $4^{\circ} \mathrm{C}$ for $15 \mathrm{~min}$ at $21000 \mathrm{~g}$. The supernatant was used for enzyme activity assay. The enzyme activities were expressed as units $\mathrm{mg}^{-1}$ protein per minute $\left(\mathrm{U} \mathrm{mg}^{-1}\right.$ protein $\left.\mathrm{min}^{-1}\right)$. The protein content was determined according to Bradford method using bovine serum albumin as a standard. The concentration of $\mathrm{H}_{2} \mathrm{O}_{2}$ was measured by the method of (Loreto, Velikova, 2001). Leaves were homogenized in an ice bath with $0.1 \%(\mathrm{w} / \mathrm{v})$ trichloroacetic acid (TCA). The extract was centrifuged at $12000 \mathrm{~g}$ for $15 \mathrm{~min}$, and $0.5 \mathrm{ml}$ of $10 \mathrm{mM}$ potassium phosphate buffer $(\mathrm{pH} 7.0)$ and $1.0 \mathrm{ml}$ of $1.0 \mathrm{M}$ potassium iodide $(\mathrm{KI})$ were added to $0.5 \mathrm{ml}$ of the supernatant, and the absorbance was read at $390 \mathrm{~nm}$. The concentration of $\mathrm{H}_{2} \mathrm{O}_{2}$ was given on a standard curve.

Gene expression. $100 \mathrm{mg}$ of leaf tissue was ground thoroughly in liquid nitrogen using a pre-chilled mortar and pestle. Total RNA was extracted by the kit $R N X$-Plus using guanidine/phenol solution according to the manufacturer's instructions ("Cinnagen", Iran). The concentration of the RNA was determined using spectrophotometer NanoDrop (Thermo Fisher Scientific, USA) at $260 \mathrm{~nm}$. Quality of the RNA was checked by both gel and NanoDrop at the 260/280 ratio.

The expression of genes was analyzed using semi-quantitative reverse transcription polymerase chain reaction (RT-PCR). First strand cDNA synthesis was created from preheated and snap cold treated $1 \mu$ l of total RNA using an oligo $(\mathrm{dT})_{16}$ primer in a $20 \mu \mathrm{l}$ reaction containing: $40 \mathrm{U}$ M-MuLV reverse transcriptase, 5x reverse transcription buffer, $20 \mathrm{U}$ inhibitor RiboLock ${ }^{\mathrm{TM}}$ RNase ("Cinnagen", Iran) $10 \mathrm{mM}$ each dNTPs. The reaction was carried out at $42^{\circ} \mathrm{C}$ for $60 \mathrm{~min}$, followed by a 10 -min step at $70^{\circ} \mathrm{C}$ and then by cooling to $4^{\circ} \mathrm{C}$.

The specific primers (Table 1) were designed according to the gene bank, by software primer 3 and IDT website (http://eu.idtdna.com). All the used primers are listed in the supplementary file. The PCR reaction by specific primers for each gene was carried out as follows: $5 \mathrm{~min}$ at $94^{\circ} \mathrm{C}$ then 25 cycles of $30 \mathrm{~s}$ at $95^{\circ} \mathrm{C}, 30 \mathrm{~s}$ at $57-60^{\circ} \mathrm{C}$ (depending on the gene), and $30 \mathrm{~min}$ at $72^{\circ} \mathrm{C}$, and a final extension of $10 \mathrm{~min}$ at $72^{\circ} \mathrm{C}$. A no reverse transcriptase control (No-RT) was performed for all samples to monitor DNA contamination. Another control was amplification of a housekeeping gene, elongation factor 1-alpha, which was done to correct for quantity and quality differences (normalize) between samples. Each experiment was repeated at least three times in order to ensure reproducibility. Quantification of the amplified bands was done by the software GelQuant.NET. Each cDNA band density was normalized by dividing it by the density of the elongation factor 1-alpha band in the same lane. The relative gene expression was calculated by dividing the band density of the gene from the treated leaves by that of the same gene from the control leaves. PCR products were detected on $1 \%$ agarose gels by ethidium bromide staining.

Table 1. Name and sequence of the used primers

\begin{tabular}{cc}
\hline Primer & Sequence (reverse/forward) \\
\hline F-EF1 & CAGATTGGCAACGGCTACG \\
R-EF1 & CGGACAGCAAAACGACCAAG \\
F-CAT & CCTTCCTCTTCGACGACATC \\
R-CAT & CCGTCGTAGTGGTTGTTGTG \\
F-APX & GGAGCGAATGCTGGTCTTAC \\
R-APX & CCTGGTCCTCTGCGTACTTC \\
F-GST & AGCTCGTCCCCATCAACTTC \\
R-GST & ACATGGTTAAGGTCCGAAG \\
\hline
\end{tabular}

Statistical analysis. The analysis of variance ( ANOVA) was performed on all experimental data using software GenStat 12. The differences between means were determined using Duncan's multiple range test at 0.05 and 0.01 probability level.

\section{Results and discussion}

Effects of fungal treatments on root colonization, dry mass and $\boldsymbol{C d}$ content. In $P$. indicainoculated and F. mosseae-inoculated plants, root colonization was significantly decreased at 0.6 and 0.9 $\mathrm{mM} \mathrm{Cd}$ compared to $0 \mathrm{mM} \mathrm{Cd}$ (Table 2). However, the sensitivity of $F$. mosseae was more than $P$. indica to $\mathrm{Cd}$ treatment at 0.6 and $0.9 \mathrm{mM} \mathrm{Cd}$. This finding is in line with results of Long et al. (2010) who reported that sensitivity of AMF symbiosis to heavy metal contaminated soil is expressed as a reduction in spore germination, hyphal growth and root colonization. In co-inoculated plants, root colonization was significantly decreased with excess of $\mathrm{Cd}$ in the soil from 0 to 0.3 and from 0.6 to $0.9 \mathrm{mM}$ $\mathrm{Cd}$. Co-inoculated plants had less root colonization than $P$. indica-inoculated ones under $0.3,0.6$ and $0.9 \mathrm{mM} \mathrm{Cd}$. AMF symbiosis is known to change physiological and biochemical properties of the host and these changes may alter the composition of root exudates which play a role in the modification of the microbial population in the mycorrhizosphere. It is likely that $\mathrm{Cd}$ treatment affects the composition of root exudates by F. mosseae (Shahabivand et al., 2012).

$\mathrm{Cd}$ is known to reduce or inhibit plant growth. In the present study and in non-inoculated plants, by increasing $\mathrm{Cd}$ concentrations in the soil, total plant dry mass was reduced; however, this reduction was significant only between 0 and $0.9 \mathrm{mM} \mathrm{Cd}$ (Table 2). Data from our work are in agreement with by Hassan et al. (2013) in sunflower. The colonization by F. mosseae increased total plant dry matter at different soil $\mathrm{Cd}$ concentrations and this increase was significant under 0 and $0.3 \mathrm{mM} \mathrm{Cd}$, in comparison with non-colonized plants. It is well known that the association of plants with mycorrhizal fungi modifies plant responses to metal-induced stress which leads to increasing tolerance in metal-contaminated 
Table 2. The effects of Funelliformis mosseae and Piriformospora indica on root colonization, biomass, and shoot and root cadmium $(\mathrm{Cd})$ contents in wheat under increasing cadmium $(\mathrm{Cd})$ in the soil

\begin{tabular}{|c|c|c|c|c|c|}
\hline $\begin{array}{l}\text { Cd level } \\
\mathrm{mM}\end{array}$ & Fungal treatment & $\begin{array}{c}\text { Root } \\
\text { colonization \% }\end{array}$ & $\begin{array}{l}\text { Total plant } \\
\text { g plant }^{-1} \\
\text { dry mass }\end{array}$ & $\begin{array}{c}\text { Shoot } \\
\mathrm{mg} \mathrm{kg}^{-1} \mathrm{Cd} \\
\text { dry weight }\end{array}$ & $\begin{array}{c}\text { Root } \\
\mathrm{mg} \mathrm{kg-1} \mathrm{Cd} \\
\text { dry weight }\end{array}$ \\
\hline 0.0 & $\mathrm{nF}, \mathrm{nP}$ & $0.0 \mathrm{~h}$ & $0.502 \mathrm{bcd}$ & $0.0 \mathrm{f}$ & $42 \mathrm{i}$ \\
\hline 0.0 & $\mathrm{~F}, \mathrm{nP}$ & $45.0 \mathrm{f}$ & $0.692 \mathrm{a}$ & $0.0 \mathrm{f}$ & $51 \mathrm{i}$ \\
\hline 0.0 & $\mathrm{nF}, \mathrm{P}$ & $61.6 \mathrm{a}$ & $0.780 \mathrm{a}$ & $0.0 \mathrm{f}$ & $33 \mathrm{i}$ \\
\hline 0.0 & $\mathrm{~F}, \mathrm{P}$ & $62.0 \mathrm{a}$ & $0.765 \mathrm{a}$ & $0.0 \mathrm{f}$ & $50 \mathrm{i}$ \\
\hline 0.3 & $\mathrm{nF}, \mathrm{nP}$ & $0.0 \mathrm{~h}$ & $0.367 \mathrm{de}$ & $81 \mathrm{e}$ & $4770 \mathrm{~g}$ \\
\hline 0.3 & $\mathrm{~F}, \mathrm{nP}$ & $43.3 \mathrm{f}$ & $0.697 \mathrm{a}$ & $70 \mathrm{e}$ & $5078 \mathrm{~g}$ \\
\hline 0.3 & $\mathrm{nF}, \mathrm{P}$ & $61.3 \mathrm{ab}$ & $0.705 \mathrm{a}$ & $74 \mathrm{e}$ & $3720 \mathrm{~h}$ \\
\hline 0.3 & $\mathrm{~F}, \mathrm{P}$ & $53.3 \mathrm{de}$ & $0.620 \mathrm{abc}$ & $77 \mathrm{e}$ & $4986 \mathrm{~g}$ \\
\hline 0.6 & $\mathrm{nF}, \mathrm{nP}$ & $0.0 \mathrm{~h}$ & $0.357 \mathrm{de}$ & $181 \mathrm{~b}$ & 7506 ef \\
\hline 0.6 & $\mathrm{~F}, \mathrm{nP}$ & $25.0 \mathrm{~g}$ & $0.380 \mathrm{de}$ & $154 \mathrm{~d}$ & $8110 \mathrm{~d}$ \\
\hline 0.6 & $\mathrm{nF}, \mathrm{P}$ & $58.0 \mathrm{bc}$ & $0.617 \mathrm{abc}$ & $171 \mathrm{bc}$ & $7148 \mathrm{f}$ \\
\hline 0.6 & $\mathrm{~F}, \mathrm{P}$ & $54.6 \mathrm{~cd}$ & $0.645 \mathrm{ab}$ & $166 \mathrm{c}$ & 7868 de \\
\hline 0.9 & $\mathrm{nF}, \mathrm{nP}$ & $0.0 \mathrm{~h}$ & $0.293 \mathrm{e}$ & $205 \mathrm{a}$ & $9522 \mathrm{c}$ \\
\hline 0.9 & $\mathrm{~F}, \mathrm{nP}$ & $22.6 \mathrm{~g}$ & $0.372 \mathrm{de}$ & $171 \mathrm{bc}$ & $10764 \mathrm{a}$ \\
\hline 0.9 & $\mathrm{nF}, \mathrm{P}$ & $55.3 \mathrm{~cd}$ & $0.482 \mathrm{bcd}$ & $199 \mathrm{a}$ & $9496 \mathrm{c}$ \\
\hline 0.9 & $\mathrm{~F}, \mathrm{P}$ & $50.0 \mathrm{e}$ & $0.470 \mathrm{~cd}$ & $179 \mathrm{~b}$ & $9960 \mathrm{~b}$ \\
\hline
\end{tabular}

Notes. $\mathrm{F}-F$. mosseae, $\mathrm{P}-P$. indica, $\mathrm{nF}-$ non-F. mosseae, $\mathrm{nP}-$ non- $P$. indica; values are mean: $\mathrm{n}=4$. The same letter within each column indicates no significant difference among treatments $(P<0.05)$ using Duncan's multiple range test.

soils (Göhre, Paszkowski, 2006). The uptake of metals by mycorrhizal plants and toxicity amelioration are major aspects to be considered by those interested in phytoremediation technologies (Ali et al., 2013). The positive effect of $F$. mosseae on growth is probably related to the improvement of mineral nutrition such as $\mathrm{P}$, the uptake of water by hyphae and the increase of root length density. Presence of $P$. indica (alone or together with $F$. mosseae) significantly increased total plant dry matter under all $\mathrm{Cd}$ concentrations in the soil (Table 2). Many researchers have shown that $P$. indica colonizes the roots of a wide variety of plant species and promotes their growth (Varma et al., 2012). However, the mechanisms behind the growth-promoting effects of $P$. indica are a matter of debate.

In our previous work a significant increase in $\mathrm{Cd}$ concentration of both wheat shoot and root was observed by increasing soil Cd concentration compared to control treatment (Shahabivand et al., 2012) (Table 2). The results from Table 2 showed that the Cd concentration in roots was more than that of soil $\mathrm{Cd}$, indicating that the $\mathrm{Cd}$ absorption mechanism for roots is an active process in wheat. It is suggested that the mechanisms of $\mathrm{Cd}$ absorption in roots and xylem loading are related to an energy-dependent active process (Mori et al., 2009). Based on Table 2, root accumulated more $\mathrm{Cd}$ than shoot. It could be calculated that only $3-4 \%$ of the total $\mathrm{Cd}$ accumulated in roots reached the shoot cells. Accumulation of large amounts of $\mathrm{Cd}$ in the roots may limit the accumulation of $\mathrm{Cd}$ in above-ground portions of wheat plants. The presence of $P$. indica (alone or together with $F$. mosseae) increased $\mathrm{Cd}$ concentration in root but decreased $\mathrm{Cd}$ content in shoot with the excess of $\mathrm{Cd}$ concentrations in the soil (Table 2). These results showed that chelation of $\mathrm{Cd}$ inside the fungus or adsorption of $\mathrm{Cd}$ to chitin in the fungal cell wall caused accumulation of $\mathrm{Cd}$ in root and prevented the $\mathrm{Cd}$ translocation from root to shoot. Similarly, in AMF, there is evidence suggesting that fungal hyphae components may provide additional detoxification mechanisms by storing toxic compounds (Göhre, Paszkowski, 2006). F. mosseae inoculation reduced root and shoot $\mathrm{Cd}$ at all $\mathrm{Cd}$ levels in the soil. The reduction in root $\mathrm{Cd}$ content under $F$. mosseae inoculation might be related to the adsorptive capability for metals of the relatively large fungal biomass (especially extraradical hyphal cell wall) associated with the host plant roots, which may physically minimize or exclude the entry of metals into host plant (Shahabivand et al., 2012).

Effects of fungal treatments on $\mathrm{H}_{2} \mathrm{O}_{2}$ content and enzyme activities. In non-inoculated plants, increasing $\mathrm{Cd}$ concentration in the soil significantly $(p<0.01)$ increased $\mathrm{H}_{2} \mathrm{O}_{2}$ contents $(1.5-2.5$ fold $)$ in wheat leaves (Table 3). Increased levels of $\mathrm{H}_{2} \mathrm{O}_{2}$ indicated that $\mathrm{Cd}$ exposure results in generation of ROS, which are highly toxic molecules and cause cellular damage in plants. In this work, we observed decreased $\mathrm{H}_{2} \mathrm{O}_{2}$ content in leaves of wheat plants colonized with $P$. indica and $F$. mosseae (alone or together, except for F. mosseaeinoculated plants at 0.6 and $0.9 \mathrm{mM} \mathrm{Cd}$ ), indicating a lower accumulation of $\mathrm{H}_{2} \mathrm{O}_{2}$ in fungi-inoculated plants. The root cells of AMF treated plants may locally induce accumulation of $\mathrm{H}_{2} \mathrm{O}_{2}$ (in the intra-cellular AM hyphae or at the intercellular hyphal surface).

In non-inoculated wheat plants, the $\mathrm{Cd}$ concentration of $0.3 \mathrm{mM}$ in the soil, significantly reduced CAT and APX activities compared to $0 \mathrm{mM}$ $\mathrm{Cd}$, whereas concentrations of 0.6 and $0.9 \mathrm{mM}$ had no further influence on CAT and APX activities compared to $0.3 \mathrm{mM} \mathrm{Cd}$ (Table 3 ). Cd stress elicits biochemical responses in higher plants that minimize its deleterious effects. One important component of protective systems is enzymatic defense. CAT dismutates reduces $\mathrm{H}_{2} \mathrm{O}_{2}$ to oxygen and water and APX reduces $\mathrm{H}_{2} \mathrm{O}_{2}$ to water by ascorbate as specific electron donor. $\mathrm{A}$ significant reduction in CAT and APX activities of wheat plants was very likely due to the harmful effect of overproduction of $\mathrm{H}_{2} \mathrm{O}_{2}$ or its poisonous ROS derivatives such as MDA (malondialdehyde) as a biomarker for oxidative stress induced under $\mathrm{Cd}$ stress.

GSTs are one of the major cellular detoxification enzymes protecting plants from oxidative stress. GST catalyzes the conjugation of various electrophiles with 
Table 3. The effects of Funelliformis mosseae and Piriformospora indica on $\mathrm{H}_{2} \mathrm{O}_{2}$ and activities of catalase (CAT), ascorbate peroxidase (APX) and glutathione S-transferase (GST) of leaves in wheat under increasing cadmium (Cd) in the soil

\begin{tabular}{|c|c|c|c|c|c|}
\hline $\begin{array}{c}\text { Cd level } \\
\mathrm{mM}\end{array}$ & Fungal treatment & $\begin{array}{c}\mathrm{H}_{2} \mathrm{O}_{2} \\
\mathrm{mmol} \mathrm{g}^{-1} \\
\text { fresh weight }\end{array}$ & $\begin{array}{c}\text { CAT } \\
\mathrm{U} \mathrm{mg}^{-1} \\
\text { protein } \mathrm{min}^{-1}\end{array}$ & $\begin{array}{c}\text { APX } \\
\mathrm{U} \mathrm{mg}^{-1} \\
\text { protein } \mathrm{min}^{-1}\end{array}$ & $\begin{array}{c}\mathrm{GST} \\
\mathrm{U} \mathrm{mg}{ }^{-1} \\
\text { protein } \mathrm{min}^{-1}\end{array}$ \\
\hline 0.0 & $\mathrm{nF}, \mathrm{nP}$ & $0.068 \mathrm{f}$ & $0.094 \mathrm{~cd}$ & $0.275 \mathrm{c}$ & $0.129 \mathrm{f}$ \\
\hline 0.0 & $\mathrm{~F}, \mathrm{nP}$ & $0.032 \mathrm{~g}$ & $0.090 \mathrm{~d}$ & $0.428 \mathrm{a}$ & $0.205 \mathrm{e}$ \\
\hline 0.0 & $\mathrm{nF}, \mathrm{P}$ & $0.040 \mathrm{~g}$ & $0.118 \mathrm{a}$ & $0.403 \mathrm{a}$ & $0.218 \mathrm{e}$ \\
\hline 0.0 & $\mathrm{~F}, \mathrm{P}$ & $0.033 \mathrm{~g}$ & $0.116 \mathrm{a}$ & $0.453 \mathrm{a}$ & $0.211 \mathrm{e}$ \\
\hline 0.3 & $\mathrm{nF}, \mathrm{nP}$ & $0.105 \mathrm{c}$ & $0.058 \mathrm{i}$ & $0.167 \mathrm{~d}$ & $0.292 \mathrm{c}$ \\
\hline 0.3 & $\mathrm{~F}, \mathrm{nP}$ & $0.059 \mathrm{f}$ & $0.076 \mathrm{fg}$ & $0.244 \mathrm{c}$ & $0.274 \mathrm{~cd}$ \\
\hline 0.3 & $\mathrm{nF}, \mathrm{P}$ & $0.067 \mathrm{f}$ & $0.100 \mathrm{~b}$ & $0.340 \mathrm{~b}$ & $0.273 \mathrm{~cd}$ \\
\hline 0.3 & $\mathrm{~F}, \mathrm{P}$ & $0.059 \mathrm{f}$ & $0.098 \mathrm{bc}$ & $0.346 \mathrm{~b}$ & $0.264 \mathrm{~d}$ \\
\hline 0.6 & $\mathrm{nF}, \mathrm{nP}$ & $0.127 \mathrm{~b}$ & $0.055 \mathrm{i}$ & $0.157 \mathrm{~d}$ & $0.340 \mathrm{~b}$ \\
\hline 0.6 & $\mathrm{~F}, \mathrm{nP}$ & $0.080 \mathrm{e}$ & $0.072 \mathrm{gh}$ & $0.235 \mathrm{c}$ & $0.330 \mathrm{~b}$ \\
\hline 0.6 & $\mathrm{nF}, \mathrm{P}$ & $0.120 \mathrm{~b}$ & $0.082 \mathrm{e}$ & $0.260 \mathrm{c}$ & $0.321 \mathrm{~b}$ \\
\hline 0.6 & F, P & $0.085 \mathrm{de}$ & $0.084 \mathrm{e}$ & $0.269 \mathrm{c}$ & $0.332 \mathrm{~b}$ \\
\hline 0.9 & $\mathrm{nF}, \mathrm{nP}$ & $0.174 \mathrm{a}$ & $0.054 \mathrm{i}$ & $0.181 \mathrm{~d}$ & $0.396 \mathrm{a}$ \\
\hline 0.9 & $\mathrm{~F}, \mathrm{nP}$ & $0.090 \mathrm{de}$ & $0.067 \mathrm{~h}$ & $0.252 \mathrm{c}$ & $0.388 \mathrm{a}$ \\
\hline 0.9 & $\mathrm{nF}, \mathrm{P}$ & $0.164 \mathrm{a}$ & $0.079 \mathrm{ef}$ & $0.279 \mathrm{c}$ & $0.387 \mathrm{a}$ \\
\hline 0.9 & $\mathrm{~F}, \mathrm{P}$ & $0.094 \mathrm{~cd}$ & $0.081 \mathrm{ef}$ & $0.267 \mathrm{c}$ & $0.385 \mathrm{a}$ \\
\hline
\end{tabular}

Notes. $\mathrm{F}-F$. mosseae, $\mathrm{P}-P$. indica, $\mathrm{nF}-$ non-F. mosseae, $\mathrm{nP}-$ non- $P$. indica; values are mean; $\mathrm{n}=4$. The same letter within each column indicates no significant difference among treatments $(P<0.05)$ using Duncan's multiple range test.

reduced glutathione, detoxifying both exogenously (such as $\mathrm{Cd}$ ) and endogenously derived toxic compounds (Dixit et al., 2011). By increasing soil Cd concentrations, GST activity was significantly increased, in non-inoculated wheat (Table 3). Similarly, the activity of GST in barley roots treated with $\mathrm{Cd}$ was significantly stimulated (Tamas et al., 2008). GST has also been suggested as main enzyme in detoxification processes in Phragmites australis exposed to high concentration of $\mathrm{Cd}$. In addition, certain plant GSTs have secondary glutathione peroxidase activity capable of reducing organic hydroperoxides protecting cells during oxidative stress (Flohé, 2012). High GST activity is a common characteristic of the most widespread Triticum aestivum cultivars, and several studies have revealed a high correlation between their GST activity and stress tolerance (Jiang, Yang, 2009).

Inoculation of $F$. mosseae increased CAT activity under $0.3,0.6$ and $0.9 \mathrm{mM}, \mathrm{APX}$ activity under all $\mathrm{Cd}$ concentrations, and GST activity under $0 \mathrm{mM} \mathrm{Cd}$ in comparison with un-inoculated plants (Table 3). Inoculation of $P$. indica (alone or together with F.mosseae) increased CAT and APX activities under all $\mathrm{Cd}$ concentrations, and GST activity in $0 \mathrm{mM}$ $\mathrm{Cd}$ compared to non-inoculated plants. GSTs have an important role in the detoxification of wide variety of toxic compounds (such as cadmium) through their conjugation to glutathione. Thus, decline in leaf GST activity under fungal inoculation at different $\mathrm{Cd}$ levels was probably due to reducing $\mathrm{Cd}$ accumulation in leaves of wheat plants after fungal inoculation (Table 2). CAT activity in leaves of AM plants has been shown to double in relation to control plants under heavy metal stress in the soil (Andrade et al., 2010). The CAT response is associated with AM colonization, and the induced activity of this enzyme by AMF can contribute to the enhanced plant growth and $\mathrm{Cd}$ tolerance of $\mathrm{AM}$ plants under $\mathrm{Cd}$ stress (Liu et al., 2011). In the case of plants colonized with $P$. indica, a 23 -fold and a 3.8-fold increased activity was found for CAT and GST, respectively, as compared to non-colonized plants (Kumar et al., 2009). The data from our study are consistent with previous observations in which activation of the antioxidant enzyme systems is a major target of $P$. indica in leaves (Sun et al., 2010). In our study, the higher CAT, APX and GST activities in AMF and endophyte fungus seedling would partly explain the lower $\mathrm{H}_{2} \mathrm{O}_{2}$ concentration (Table 3 ) in these seedlings, protecting the organism against oxidative damage, which in turn enhances $\mathrm{Cd}$ tolerance.

Gene expression in response to fungi. The analysis of transcriptional level of the three antioxidant genes in leaves was examined by semi-quantitative RTPCR. Transcript levels of CAT, APX and GST genes were altered in response to different $\mathrm{Cd}$ concentrations in uncolonized plants (Fig. 1).

Expression levels of CAT were decreased under 0.3, 0.6 and $0.9 \mathrm{mM} \mathrm{Cd}$ compared to $0 \mathrm{mM} \mathrm{Cd}$ (Fig. 2). However, CAT expression level was higher at $0.9 \mathrm{mM}$ than 0.3 and $0.6 \mathrm{mM} \mathrm{Cd}$. The decrease in CAT transcription was consistent with the change in CAT enzyme activity. In pea plants, it was found that $\mathrm{Cd}$ caused a reduction in the enzyme activities and transcription of two isoforms of superoxide dismutase (CuZn-SODs and Mn-SOD) but up-regulated the expression of Fe-SOD isoform (Rodriguez-Serrano et al., 2006). In the case of APX, in contrast to the overall changes in enzyme activity, an induction was observed after application of $0.3,0.6$ and $0.9 \mathrm{mM} \mathrm{Cd}$ (Fig. $2 \mathrm{~B}$ ). Wu et al. (2009) reported that transcriptional level of CAT and APX declined in response to $\mathrm{Cd}$ accumulations in Ulva fasciata while an increase in enzyme activity was observed in higher concentrations. In contrast, CAT and APX were upregulated transcriptionally in leaves of Arabidopsis thaliana under Cd stress (Smeets et al., 2008) whereas CAT enzymatic activity did not change significantly. They also showed that $\mathrm{Cd}$ caused accumulation of glutathione reductase (GR) transcripts, on the other hand, GR enzymatic activity decreased in leaves. It is likely that $\mathrm{Cd}$ interacts with the translation complex, reducing the activity of APX, or may be Cd alters the turnover of the enzyme. As shown by Cuypers et al. (2010), an oxidative modification could be induced by $\mathrm{Cd}$ exposure which possibly led to higher proteolytic degradation. 
Also, it has been indicated that $\mathrm{Cd}$ stress can result in protein denaturation in $A$. thaliana (Semane et al., 2010). Similar to APX, transcriptional pattern of GST represented an increasing trend (Figs 1 and $2 \mathrm{C}$ ). As the Cd concentration rose from 0 to $0.3 \mathrm{mM}$, GST transcripts started to increase rapidly reaching the maximum at $0.6 \mathrm{mM} \mathrm{Cd}$. This change agreed with the rise in GST activity. The coincidence between GST activity and its transcript level implies that the induction of activity of this enzyme by $\mathrm{Cd}$ is attributable to enhanced expression of GST.

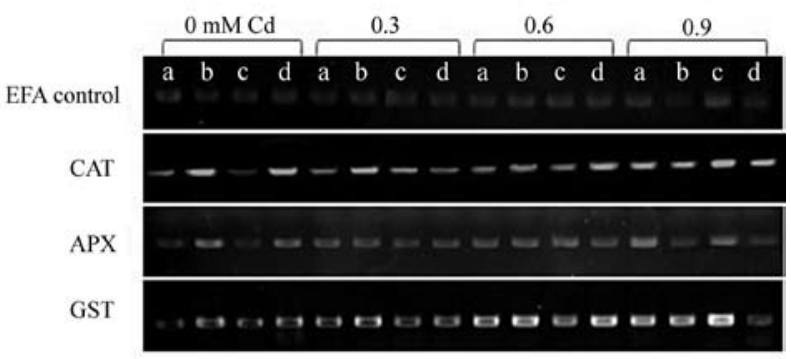

Notes. The effects of Funelliformis mosseae and Piriformospora indica on gene expression in wheat leaves under increasing cadmium $(\mathrm{Cd})$ in the soil are represented. Elongation factor 1-alpha was used as internal control gene to normalize different samples. a - control (non-inoculation), b - F. mosseae, c $P$. indica, $\mathrm{d}-F$. mosseae $+P$. indica. Experiments were repeated three times.

Figure 1. Analysis of mRNA expression of the antioxidant genes by semi-quantitative RT-PCR

Furthermore, the transcription levels of these genes were determined in the leaves after application of three fungal treatments. As shown in Figure $2 \mathrm{~A}$, an increase in CAT transcript level was detectable in 0.3, 0.6 and $0.9 \mathrm{mM} \mathrm{Cd}$ concentrations in the colonized plants in comparison with uncolonized control; however, this increase was not significant for $P$. indica in $0 \mathrm{Mm} \mathrm{Cd}$. Fungus $F$. mosseae and mix-colonization ( $F$. mosseae + $P$. indica) caused induction in CAT transcription at all Cd levels, and $P$. indica caused induction in 0.3, 0.6 and $0.9 \mathrm{mM} \mathrm{Cd}$ in comparison with non-colonized plants (Fig. 2 A). In $0 \mathrm{Cd} \mathrm{mM}$ level, similar results were obtained for APX gene as transcription level were increased in colonized wheat with the exception of $P$. indica that could not induce APX transcription significantly (Fig. 2 B). Interaction effects between fungus and the $\mathrm{Cd}$ levels were slightly different from the main effects $(0 \mathrm{mM} \mathrm{Cd}) ; F$. mosseae caused induction of the gene only at $0 \mathrm{mM} \mathrm{Cd}$ and $P$. indica and co-colonization induced APX transcription at 0.3 and $0.6 \mathrm{mM} \mathrm{Cd}$. But, APX was down-regulated in the all colonized plants at $0.9 \mathrm{mM}$ $\mathrm{Cd}$. These alternations were rather similar to those of enzyme activity where both $F$. mosseae and $P$. indica had the most impact on the enzyme activity in $0 \mathrm{mM} \mathrm{Cd}$ levels. Fungal treatments including $F$. mosseae, $P$. indica and mix-colonization were able to up-regulate GST expression notably in $0 \mathrm{mM} \mathrm{Cd}$. Fungus $F$. mosseae and mix-colonization increased transcription level in all $\mathrm{Cd}$ concentrations except $0.9 \mathrm{mM}$ in which mix-colonized plants reduced GST transcripts (Fig. 2 C). Also, $P$. indica induced GST transcription in 0 and $0.9 \mathrm{mM} \mathrm{Cd}$ but reduced its transcription in 0.3 and $0.6 \mathrm{mM} \mathrm{Cd}$. On the other hand, the effects of three fungal treatments were not significant in APX, CAT and GST activity in 0.3, 0.6

\section{A}

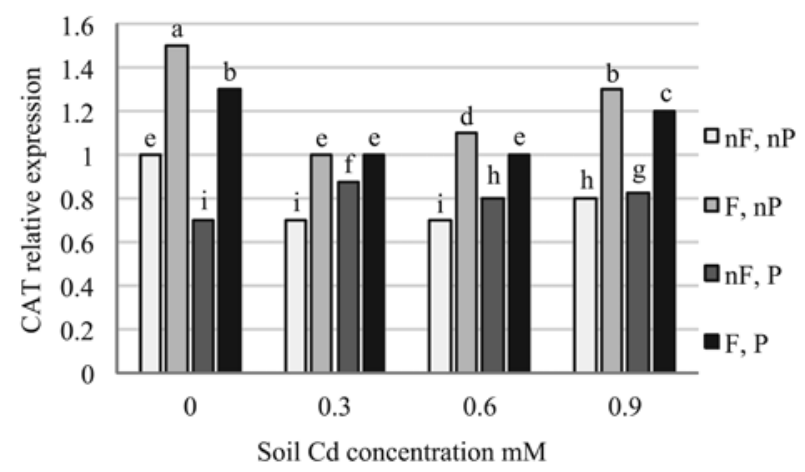

B

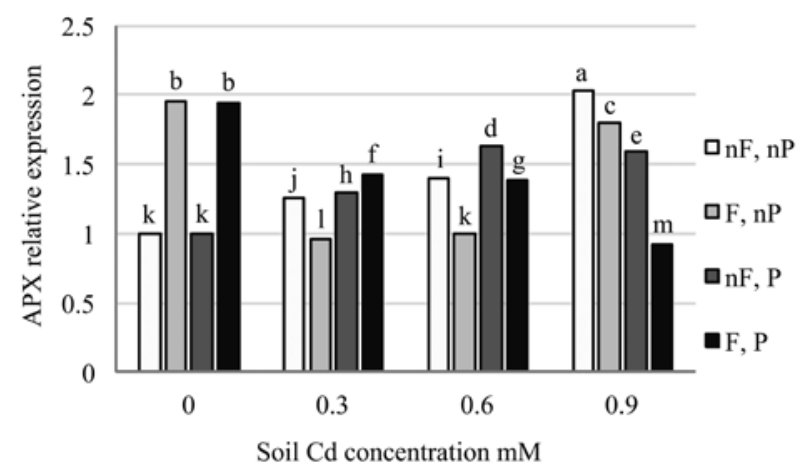

C

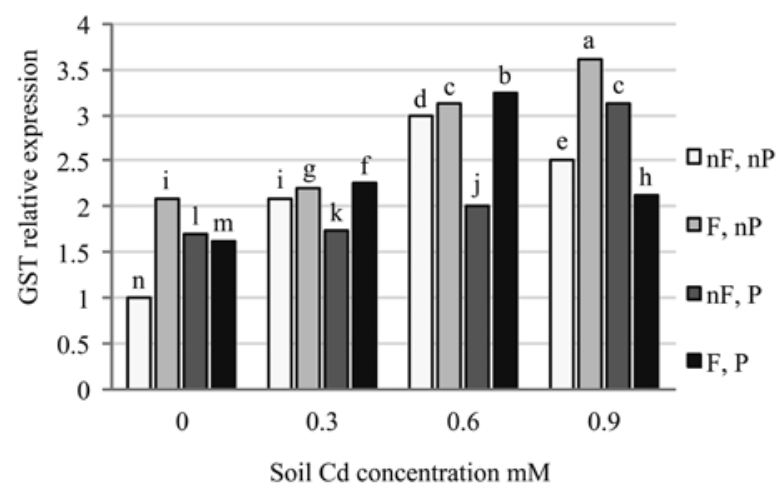

Notes. $\mathrm{F}-F$. mosseae, $\mathrm{P}-P$. indica, $\mathrm{nF}-$ non-F. mosseae, $\mathrm{nP}-$ non-P. indica. Values with different letter are significantly different at $p<0.01$; mean $\pm \mathrm{SE}$ of three independent experiments.

Figure 2. The effects of Funelliformis mosseae and Piriformospora indica on the expression of three genes catalase (CAT) (A), ascorbate peroxidase (APX) (B) and glutathione S-transferase (GST) (C) in wheat under increasing cadmium $(\mathrm{Cd})$ in the soil

and $0.9 \mathrm{mM} \mathrm{Cd}$. Post-transcriptional regulation is likely to play a key role in this case. These differences might be due to the presence of multiple allo or isozymes. Alternatively, an enhanced breakdown of the proteins can be caused by $\mathrm{Cd}$ concentrations, which in turn also results in high level of transcription (Smeets et al., 2008). Fungus $F$. mosseae had a positive impact on transcript accumulation of stress genes. Interestingly, this positive effect was not detected in some of $P$. indica-colonized plants. In particular, the main effects of this fungus were not remarkable, resulting in no significant induction in transcription of the studied antioxidant genes. Therefore, influence of mix-colonization treatment, particularly in 
main effects, mostly resulted from $F$. mosseae activity. Molitor et al. (2011) indicated that $P$. indica could induce transcription of a wide range of pathogenesis-related genes and they concluded that $P$. indica likely induced disease resistance through genes encoding heat-shock proteins.

It is believed that regulation of antioxidant enzymes is performed post-translationally under oxidative stress (Sun et al., 2010), therefore, it seems that measurement of enzymatic activity is more reliable for the evaluation of $P$. indica and $F$. mosseae effects than expression level. Increase in antioxidant activity was a major target for $P$. indica in barely leaves. However, it has been showed that $P$. indica is able to up-regulate droughtrelated genes in Arabidopsis leaves colonized by $P$. indica (Sherameti et al., 2008). Our findings suggest that $P$. indica may function more through enhancing enzyme activity than inducing transcription under cadmium toxicity. The alteration of antioxidative defence genes in plants colonized by mycorrhiza has previously been investigated. For example, in mycorrhiza-colonized lettuce, Mn-SOD2 transcripts accumulated under water stress which led to a higher resistance in plants (Gill, Tuteja, 2010). They also found that expression level of SOD genes were reduced in non-stress conditions. Bagheri et al. (2013) revealed that GST transcription and its protein synthesis were induced in mycorrhiza-colonized plants. Transcriptional induction in the studied antioxidant genes in the $F$. mosseae-colonized wheat, in present work, was consistent with the abovementioned studies.

\section{Conclusions}

1. Cadmium $(\mathrm{Cd})$ toxicity significantly altered enzyme activity and transcription level of catalase (CAT), ascorbate peroxidase (APX) and glutathione S-transferase (GST).

2. Inoculation of wheat plants with arbuscular mycorrhizal and root-endophytic fungi could be efficient to reduce Cd stress.

3. Both Funelliformis mosseae and Piriformospora indica confer tolerance to $\mathrm{Cd}$ stress in pot cultured wheat by increasing plant dry mass and antioxidant enzyme activities.

4. No coincidence was observed between enzyme activity and transcription in some treatments, showing that these enzymes are not under transcriptional regulation.

Received 17082015

Accepted 10122015

\section{References}

Ali H., Khan E., Sajad M. A. 2013. Phytoremediation of heavy metals: concepts and applications. Chemosphere, 91 (7): $869-881$

http://dx.doi.org/10.1016/j.chemosphere.2013.01.075

Andrade S. A. L., Gratao P. L., Azevedo R. A., Silveria A. P. D., Schiavinato M. A., Mazzafera P. 2010. Biochemical and physiological changes in jack bean under mycorrhizal symbiosis growing in soil with increasing $\mathrm{Cu}$ concentrations. Environmental and Experimental Botany, 68: 198-207 http://dx.doi.org/10.1016/j.envexpbot.2009.11.009

Bagheri A. A., Saadatmand S., Niknam V., Nejadsatari T., Babaeizad V. 2013. Effect of endophytic fungus, Piriformospora indica, on growth and activity of antioxidant enzymes of rice (Oryza sativa L.) under salinity stress. International Journal of Advanced Biological and Biomedical Research, 1 (11): 1337-1350

Cuypers A., Plusquin M., Remans T., Jozefczak M., Keunen E., Gielen H., Opdenakker K., Nair A. R., Munters E., Artois T. J. 2010. Cadmium stress: an oxidative challenge. Biometals. 23: 927-940 http://dx.doi.org/10.1007/s10534-010-9329-x

Dixit P., Mukherjee P. K., Ramachandran V., Eapen S. 2011. Glutathione transferase from Trichoderma virens enhances cadmium tolerance without enhancing its accumulation in transgenic Nicotiana tabacum. PLOS ONE. 6 (1): e16360 http://dx.doi.org/10.1371/journal.pone.0016360

Flohé L. 2012. Glutathione peroxidases. Selenoproteins and mimics. Berlin, Heidelberg, p. 1-25

Gao C., Wang C., Zheng L., Wang L., Wang Y. 2012. A LEA gene regulates cadmium tolerance by mediating physiological responses. International Journal of Molecular Sciences, 13 (5): $5468-5481$ http://dx.doi.org/10.3390/ijms 13055468

Gill S. S., Tuteja N. 2010. Reactive oxygen species and antioxidant machinery in abiotic stress tolerance in crop plants. Plant Physiology and Biochemistry. 48 (12): 909-930 http://dx.doi.org/10.1016/j.plaphy.2010.08.016

Göhre V., Paszkowski U. 2006. Contribution of the arbuscular mycorrhizal symbiosis to heavy metal phytoremediation. Planta. 223: 1115-1123

http://dx.doi.org/10.1007/s00425-006-0225-0

Hassan S. E., Hijri M., St-Arnaud M. 2013. Effect of arbuscular mycorrhizal fungi on trace metal uptake by sunflower plants grown on cadmium contaminated soil. New Biotechnologv. 30 (6): 780-787 http://dx.doi.org/10.1016/j.nbt.2013.07.002

Jiang L., Yang H. 2009. Prometryne-induced oxidative stress and impact on antioxidant enzymes in wheat. Ecotoxicology and Environmental Safetv. 72 (6): 1687-1693 http://dx.doi.org/10.1016/j.ecoenv.2009.04.025

Kumar K., Yadav V., Tuteja N., Johri A. K. 2009. Antioxidant enzyme activities in maize plants colonized with Piriformospora indica. Microbiology. 155: 780-790 http://dx.doi.org/10.1099/mic.0.019869-0

Kumar V., Sahai V., Bisaria V. S. 2011. High-density spore production of Piriformospora indica, a plant growth promoting endophyte, by optimization of nutritional and cultural parameters. Bioresource Technology, 102: 3169-3175

http://dx.doi.org/10.1016/j.biortech.2010.10.116

Kumar S., Asif M. H., Chakrabarty D., Tripathi R. D., Dubey R. S., Trivedi P. K. 2013. Expression of a rice Lambda class of glutathione S-transferase, OsGSTL2, in Arabidopsis provides tolerance to heavy metal and other abiotic stresses. Journal of Hazardous Materials. 248: 228-237 http://dx.doi.org/10.1016/j.jhazmat.2013.01.004

Liu L. Z., Gong Z. Q., Zhang Y. L., Li P. J. 2011. Growth, cadmium accumulation and physiology of marigold (Tagetes erecta L.) as affected by arbuscular mycorrhizal fungi. Pedosphere, 21:319-327 http://dx.doi.org/10.1016/S1002-0160(11)60132-X

Long L. K., Yao Q., Guo J., Yang R. H., Huang Y. H., Zhu H. H. 2010. Molecular community analysis of Arbuscular mycorrhizal fungi associated with five selected plant species from heavy metal polluted soils. European Journal of Soil Biology. 46 (5): 288-294 http://dx.doi.org/10.1016/j.ejsobi.2010.06.003

Loreto F., Velikova V. 2001. Isoprene produced by leaves protects the photosynthetic apparatus against zone damage, quenches ozone products, and reduces lipid peroxidation of cellular membranes. Plant Physiology, 127: 1781-1787 http://dx.doi.org/10.1104/pp.010497

Molitor A., Zajic D., Voll L. M., Pons-Kühnemann J., Samans B., Kogel K. H., Waller F. 2011. Barley leaf transcriptome and metabolite analysis reveals new aspects of compatibility and Piriformospora indica-mediated systemic induced resistance to powdery mildew. Molecular Plant-Microbe Interactions. 24 (12): 1427-1439 http://dx.doi.org/10.1094/MPMI-06-11-0177 
Mori S., Uraguchi S., Ishakawa S., Arao T. 2009. Xylem loading process is a critical factor in determining $\mathrm{Cd}$ accumulation in the shoots of Solanum melongena and Solanum torvum. Environmental and Experimental Botanv. 67: 127-132 http://dx.doi.org/10.1016/j.envexpbot.2009.05.006

Oelmüller R., Sherameti I., Tripathi S., Varma A. 2009. Piriformospora indica, a cultivable root endophyte with multiple biotechnological applications. Svmbiosis. 19: 1-19 http://dx.doi.org/10.1007/s13199-009-0009-y

Pozo M. J, Azcón-Aguilar C. 2007. Unraveling mycorrhizainduced resistance. Current Opinion in Plant Biology, 10: 393-398 http://dx.doi.org/10.1016/j.pbi.2007.05.004

Rodriguez-Serrano M., Romero-Puertas M. C., Zabalza A., Corpas F. J., Gomez M., Del Rio L. A., Sandalio L. M. 2006. Cadmium effect on oxidative metabolism of pea (Pisum sativum L.) roots. Imaging of reactive oxygen species and nitric oxide accumulation in vivo. Plant, Cell and Environment. 29 (8): 1532-1544 http://dx.doi.org/10.1111/j.1365-3040.2006.01531.x

Semane B., Dupae J., Cuypers A., Noben J. P., Tuomainen M., Tervahauta A., Vangronsveld J. 2010. Leaf proteome responses of Arabidopsis thaliana exposed to mild cadmium stress. Journal of Plant Physiology. 167 (4): 247-254 http://dx.doi.org/10.1016/j.jplph.2009.09.015

Shahabivand S., Zare-Maivan H., Goltapeh E. M., Sharifi M., Aliloo A. A. 2012. The effects of root endophyte and arbuscular mycorrhizal fungi on growth and cadmium accumulation in wheat under cadmium toxicity. Plant Physiology and Biochemistry. 60: 53-58 http://dx.doi.org/10.1016/j.plaphy.2012.07.018

Sherameti I., Tripathi S., Varma A., Oelmüller R. 2008. The root-colonizing endophyte Piriformospora indica confers drought tolerance in Arabidopsis by stimulating the expression of drought stress-related genes in leaves. Molecular Plant-Microbe Interactions. 21: 799-807 http://dx.doi.org/10.1094/MPMI-21-6-0799
Singh Gill S., Tuteja N. 2011. Cadmium stress tolerance in crop plants: probing the role of sulfur. Plant Signaling and Behavior. 6 (2): 215-222

http://dx.doi.org/10.4161/psb.6.2.14880

Smeets K., Ruytinx J., Semane B., Belleghem F. V., Remans T., Sanden S. V., Vangronsveld J., Cuypers A. 2008. Cadmiuminduced transcriptional and enzymatic alterations related to oxidative stress. Environmental and Experimental Botany, 63: $1-8$ http://dx.doi.org/10.1016/j.envexpbot.2007.10.028

Sun C., Johnson J. M., Cai D., Sherameti I., Oelmüller R., Lou B. 2010. Piriformospora indica confers drought tolerance in Chinese cabbage leaves by stimulating antioxidant enzymes, the expression of drought-related genes and the plastid-localized CAS protein. Journal of Plant Physiology, 167: 1009-1017 http://dx.doi.org/10.1016/j.jplph.2010.02.013

Tamas L., Dudikova J., Durcekova K., Huttova J., Mistrik I., Zelinova V. 2008. The impact of heavy metals on the activity of some enzymes along the barley root. Environmental and Experimental Botany, 62 (1): 86-91 http://dx.doi. org/10.1016/j.envexpbot.2007.07.009

Varma A., Bakshi M., Lou B., Hartmann A., Oelmueller R. 2012. Piriformospora indica: a novel plant growth-promoting mycorrhizal fungus. Agricultural Research, 1 (2): 117-131 http://dx.doi.org/10.1007/s40003-012-0019-5

Wu T. M., Hsu Y. T., Lee T. M. 2009. Effects of cadmium on the regulation of antioxidant enzyme activity, gene expression, and antioxidant defenses in the marine macroalga Ulva fasciata. Botanical Studies, 50: 25-34

Yoshimura K., Yabuta Y., Ishikawa T., Shigeoka A. 2000. Expression of spinach ascorbate peroxidase isoenzymes in reponse to oxidative stresses. Plant Physiology, 123: 223-233 http://dx.doi.org/10.1104/pp.123.1.223

ISSN 1392-3196 / e-ISSN 2335-8947

Zemdirbyste-Agriculture, vol. 103, No. 1 (2016), p. 53-60

DOI 10.13080/z-a.2016.103.007

\title{
Kviečių antioksidacinis aktyvumas ir genų raiška sąveikoje su mikoriziniais grybais kadmiu užterštame dirvožemyje
}

\author{
S. Shahabivand ${ }^{1,2}$, H. Z. Maivan ${ }^{1}$, E. Mahmoudi ${ }^{1}$, B. M. Soltani ${ }^{1}$, M. Sharifi ${ }^{1}$, A. A. Aliloo ${ }^{2}$ \\ ${ }^{1}$ Tarbiat Modares universitetas, Iranas \\ ${ }^{2}$ Maragheh universitetas, Iranas
}

\section{Santrauka}

Tirta Funelliformis mosseae ir Piriformospora indica įtaka kviečių augimui, fermentu aktyvumui, katalazès genų ekspresijai, askorbato peroksidazei ir glutationo S-transferazei kviečių lapuose, esant skirtingam kadmio (Cd) toksiškumui. Kadmis sumažino augalų sausają masę ir kalatazės bei askorbato peroksidazės fermentų aktyvumą, bet padidino glutationo S-transferazès aktyvumą. F. mosseae ir $P$. indica (po vieną ir kartu) padidino augalų sausają masę ir kalatazès, askorbato peroksidazès bei glutationo S-transferazès aktyvumą. Reaguojant ị $\mathrm{Cd}$ poveiki, sumažèjo transkripcinis kalatazès lygis, tačiau askorbato peroksidazès ir glutationo S-transferazès transkripcija padidejjo. Nors $F$. mosseae sukèlè antioksidacinių genų ekspresiją, $P$. indica neturèjo tokio stipraus poveikio suaktyvinant genų ekspresiją. Tyrimo rezultatai rodo, kad $F$. mosseae ir $P$. indica naudotini siekiant sušvelninti Cd stresą kviečių augaluose, auginamuose $\mathrm{Cd}$ užterštoje dirvoje. Taip pat kai kuriais atvejais nebuvo nustatyta koreliacija tarp iRNA ir fermentų pokyčių; tai rodo, kad didelès įtakos gali turèti posttranskripcinè ir posttransliacinė genų raiškos reguliacija.

Reikšminiai žodžiai: Funelliformis mosseae, genų ekspresija, kadmis, kviečiai, Piriformospora indica.

Please use the following format when citing the article:

Shahabivand S., Maivan H. Z., Mahmoudi E., Soltani B. M., Sharifi M., Aliloo A. A. 2016. Antioxidant activity and gene expression associated with cadmium toxicity in wheat affected by mycorrhizal fungus. ZemdirbysteAgriculture, 103 (1): 53-60 DOI 10.13080/z-a.2016.103.007 